\title{
中國 西部科鼠院
}

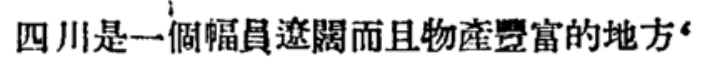
在地下埋藏着多種的瀜产, 地面上生長的動植物. 以及農業生產品的䈏足尤强可觀。在二十年前, 國 人並汥注重到應怎樣去開發它或利用它, 使其成 筒更有利於人民生部的资源。於一九三○年十月， 由虚作孚先生於羪難的情况论下, 在重度附近的 北磅創了中國西部科學院; 因感到科學研究與 調查工作的重要, 所以前後設立了理化、地質、生 物、晨林四個研究所, 並且附設了圖畫舘、博物舘 以及争善中學拿。於一九三六年, 將附設之圖書管 和博物舘交給地方辦理。一儿三:七年容, 又停辦生 物及農林兩研究所。後來, 附設的㣴善中學也脫開 本完而獨立辦理了。故自一儿三年到現在仍繼

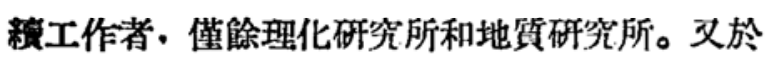
一九三八年二月四川省地質調枯所成立於重度以 後, 本院擬與合作, 將本院地質研究所的全部人員

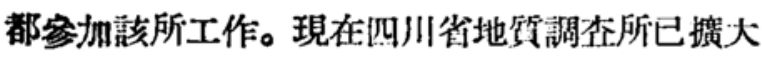
改組舀西南地質調查所, 本院已合作之工作人員 仍在西南地質調查所工作。

\section{以往工作逑要}

本院的工作目標在調查研究中國西部各省之 資源情况。糜年來的工作已有相賞成績。研究調查 的結果, 除旗要刊成報告, 供工端各界作㗅發事業 的根據及寥考外, 並隨時協助济業界解决各種問 題, 使科祭研究工作與生坣發生密切聯系。一九三

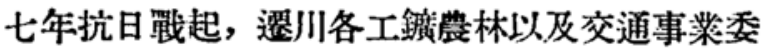
託本院調查化驗其所需原料, 根㨜本院調查研究 結果,以學辦事業者篬數甚多。抗戰期間，國內公 私學術機關, 如中國科學妍生物研究所、前中央地 質調查所、前中央工業試驗所、前中央研究院動 物、植物與氣像研究所等, 十餘單位均遥來北碚借

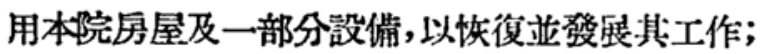
、本院均盡可能予以協助。當時北碚成品我國學術 界的重心,有助於中國學術界元氣之保保, 也点中 國西部博物舘能於一九四四年目生之最大因菜。

理化研究所自一九三○年十月成立以來, 迄 今已二十年,工作米會中斷過。其工作目標是研究 試驗四川及西部各省地面及地下物瓷的性犋和利
用。以往工作着車於(一)燃料問題之研究; (二)䤶 育及其他物料之分析; (三)化工同題之研究侙驗; (四)農產加工之研究。地兵䂰究所的工作注意於

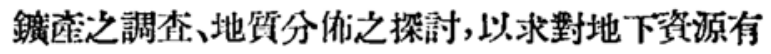

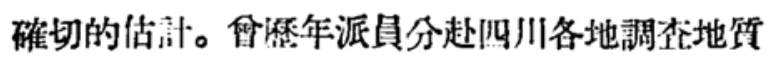
鈸産, 所獲結果多已刊第報告以供各方參若。生物

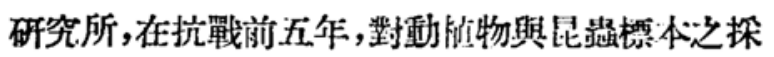
集, 進行薄第積極, 所收獲的也很多, 可惜团中途 停頓, 標本已饍西部博物管。费林研究所對果樹 及油桐之培育推廣, 筸有相常工作。附設之北碚氣 象测候所,自一九三五年一月一日起, 阔始觀测纕 續未嗫, 一九四齐年一月一日始交給中央乘像局 接管, 一追到現在。

\section{理化研究所一九五O年工作計割}

本院現在只有理化、地领网所。地啠所的人員 已參州西南地演調查所工作, 故目前僅有理化研 究所繼絃工作。

理化研究所現有工作人員公人。設橵则佳谁

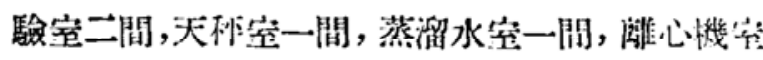

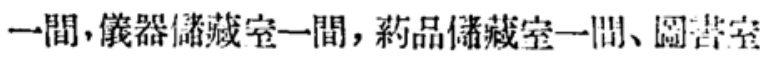

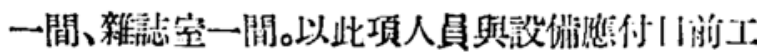

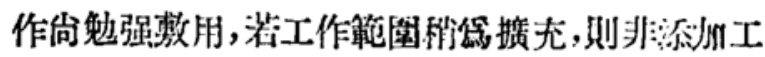

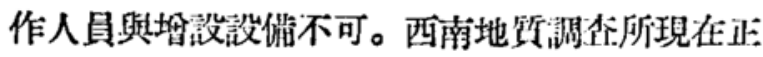

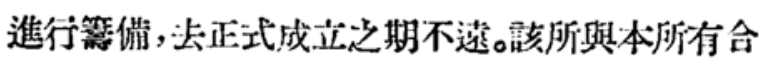
作之約, 將來淍查工作援展後, 大量㧼品源源而 來, 化驗工作人員也必須派加才能磼付工作的富 要。

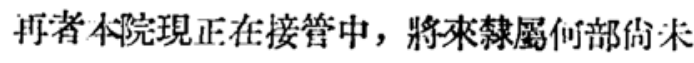

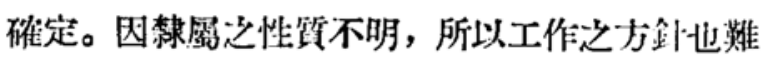

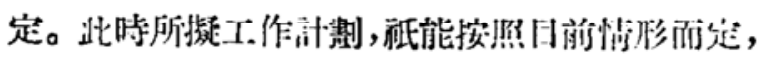

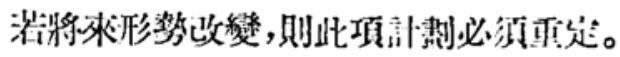

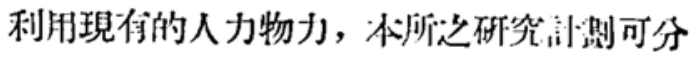
顸:

(一)接受外界委代化驗一一本年度仍照以往 辦法, 接受外界选來化驗之樣品, 如桨、水、鉝石及 其他，照規定取掠。

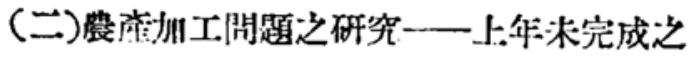
(下接籍271页) 